Corresponding Author: Vladimir Ivanovich Zhuchkov ntm2000@mail.ru

Received: 5 February 2019

Accepted: 6 March 2019

Published: 17 March 2019

Publishing services provided by Knowledge E

(c) Vladimir Ivanovich Zhuchkov et al. This article is distributed under the terms of the

Commons Attribution License, which permits unrestricted use and redistribution provided that the original author and source are credited.

Selection and Peer-review under the responsibility of the NIOKR-2018 Conference Committee.

\section{Situation and Development of Ferroalloy Metallurgy in Russia}

\author{
Vladimir Ivanovich Zhuchkov¹, Leopold Igorevich Leontiev², and \\ Veniamin Yakovlevich Dashevsky ${ }^{3}$ \\ ${ }^{1}$ Institute of Metallurgy UB RAS, Yekaterinburg, Russia \\ ${ }^{2}$ Presidium of RAS, Moscow, Russia \\ ${ }^{3}$ Baikov Institute of Metallurgy and Materials Science, RAS, Moscow, Russia
}

\section{Abstract}

Ferroalloy production is an important branch of metallurgy having a great impact on its development since the treatment of liquid metals by ferroalloys remains one of the main methods to regulate the quality of steel, cast iron,and nonferrous alloys. Manganese is the most essential element to treat ferrous and non-ferrous metals. A need for manganese alloys in Russia averages to 600-650 metric tons per year, but only a half of the quantity is satisfied by the domestic production. In contrast to manganese alloys, Russia provides itself with chromium ferroalloys obtained with the use of foreign raw materials. Domestic ores are used in limited quantities. Taking into account the strategic importance of ferroalloy industry and the necessity to create and include manganese and chromium ore bases, as well as the other basic problems, the achievement of the goals has to be implemented by enterprises with the help of the State. The output of ferrosilicon and crystal silicon in the Russian Federation exceeds its consumption in the country due to raw material reserves (quartzite, quartz), high productive capacity, and consumer demands. Ferroalloy enterprises in Russia produce ferrovanadium, ferromolybdenum, ferroniobium, ferrotungsten, ferrotitanium, and ferronickel. A traditional challenge for ferroalloy enterprises in Russia is improving the competitiveness at the expense of reducing production costs, improving the production quality, and solving the issue of import substitution for certain types of ferroalloys.

Keywords: ferroalloys, manganese, ferrochromium, production

\section{Introduction}

Ferroalloy production is an important branch of metallurgy having a great impact on its development since the treatment of liquid metals by ferroalloys remains one of the main methods to regulate the quality of steel, cast iron and nonferrous alloys. Ferroalloy metallurgy has its own features such as wide range of products, a variety of working units, a set of technological variants for obtaining ferroalloys, the position between raw 
material sources and production consumers and the dependence on their capacities and needs.

The output of steel and other alloys defines the output of ferroalloys. In 2000, the annual world output averaged 800 million tons for steel and 18 million tons for ferroalloys, in 2012 - 560 million tons for steel and 38 million tons for ferroalloys, and in 2013-2017 $-1,620-1,670$ million tons for steel and 40 million tons for ferroalloys [1-3].

Stricter requirements for steel quality lead to increasing the production of alloyed types of steel and, as a consequence, to increasing of the specific ferroalloy consumption. The average world consumption of all types of ferroalloys per steel unit was 22.5 kg/t. in 2001, $27.1 \mathrm{~kg} / \mathrm{t}$. in 2012 and 30 kg/t. in 2015 .

The main producers of ferroalloys and silicon in the Russian Federation: JSC "Chelyabinsk Electrometallurgical Plant" (ChEMK), the city of Chelyabinsk; JSC "Serov Ferroalloy Plant" (SFP), Serov, Sverdlovsk region; JSC "Kuznetskie Ferrosplavy", Novokuznetsk, Kemerovo region; PJSC “Kluchevskiy Ferroalloy Plant”, Dvurechensk, Sverdlovsk region; PJSC “ RUSAL Bratsk”, Bratsk, Irkutsk region; JSC “Kosaya Gora Iron Works", Kosaya gora, Tula region; OJSC "Satkinsky Iron Smelting Plant", Satka, Chelyabinsk region; LLC “Tikhvinsky Ferroalloy Plant”, Tikhvin, Leningrad region. Moreover, there are more than 20 smaller ferroalloy producers both independent and as part of metallurgical plants (Figure 1 [1]).

The structure of ferroalloy production in Russia is different than worldwide. The world ferroalloy production structure has not significantly changed in recent decades and corresponds to its consumption. Manganese alloys are on the first place by output in the world. Ferroalloys consumption in individual countries is balanced by export and import, and the production depends basically on the mineral and raw materials base [3-6].

In Russia, it was produced 2018 metric tons of various ferroalloys in 2017 [7].

The structure of ferroalloy production in Russia is also predetermined by domestic reserves of raw materials. The most produced ferroalloys are silicon ones (49.4\%) as they have unlimited raw material base, then manganese (25.8\%) and chromium ones (16.4\%) (Figure 2). The other ferroalloys average $9 \%$ of the production.

The production of individual ferroalloys in the Russian Federation is considered above [4-6]. 


\subsection{Manganese ferroalloys}

Manganese is the most essential element to treat ferrous and non-ferrous metals. Its world consumption averages $44-47 \%$ of all used additives.

As Russia does not have high-quality manganese ores at an appropriate level (in the first place because of the low content of manganese and high content of phosphorus), they are not mined on the territory of the country in a practical manner. Only 66 metric tons per year of the ore is extracted, whereas the requirements of the Russian plants come up to 1,020 metric tons [4].

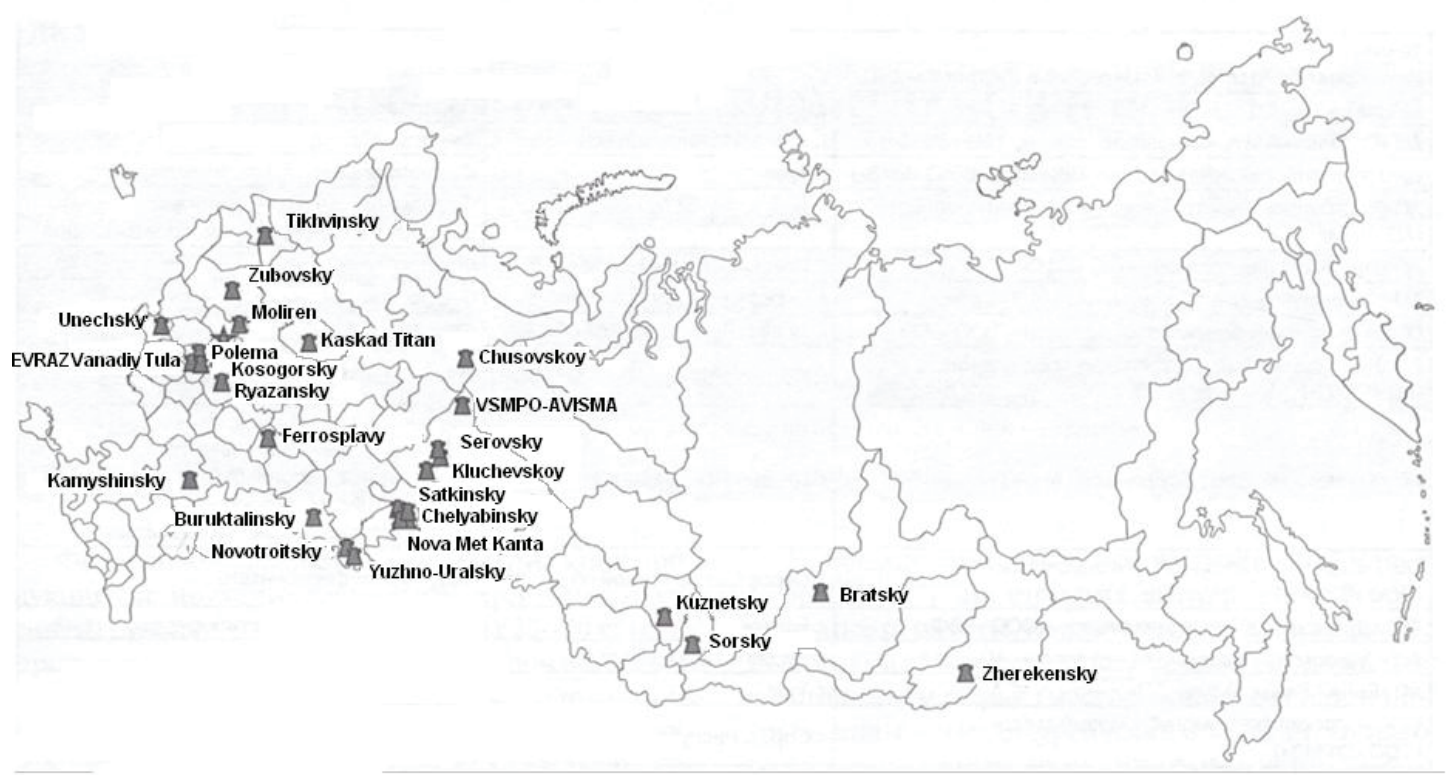

Figure 1: Ferroalloy enterprises in the Russian Federation.

Shipments of Nikopol manganese concentrates (Ukraine) were stopped in 2000, and recently manganese raw materials are supplied mainly by Kazakhstan, South Africa and, in smaller quantities, by Bulgaria and Gabon (Figure 2).

The most consumed manganese ferroalloys are ferro- and silicon-manganese (>95\%) and less consumed - low-carbon ferromanganese and metallic manganese. Before 1999, the consumption levels of ferromanganese and silicon-manganese in Russia were rather equal, but recently the consumption of silicon-manganese increases. The production of manganese in Russia is twice as high as ferromanganese smelting in the recent years [1]. In the Figure 3 one may see the data about the production, import and export of manganese ferroalloys in the Russian Federation from 1996 to 2016 according to G. Yu. Boyarko and V.Yu. Khat'kov [4].

The main producers of manganese ferroalloys in Russia are ChEMK, Kosaya Gora Iron Works and Satkinsky Iron Smelting Plant. 


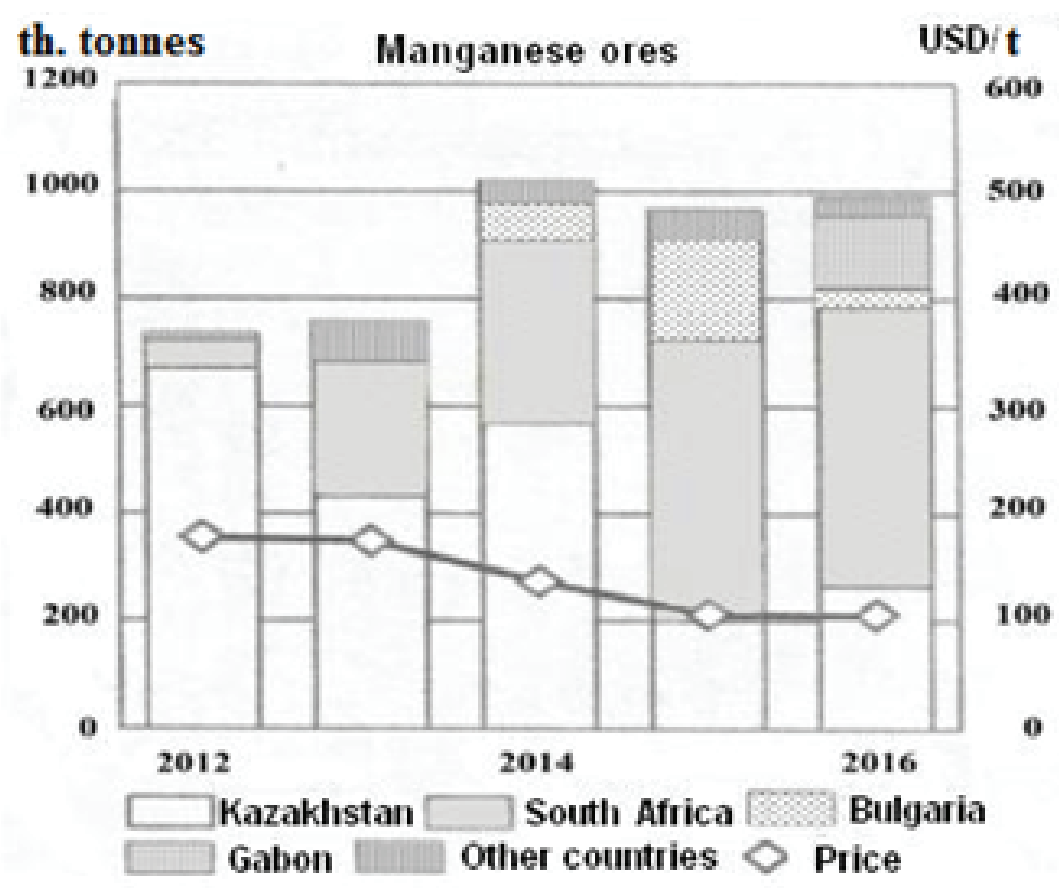

Figure 2: A flow of raw materials to Russia and its price.

At steel smelting level of 70 million tons, the need in manganese alloys averages 600 000- 650000 tons per year; however, only half of this amount is produced domestically. Thus, the plants work with imported raw materials, and a lack of manganese ferroalloys is also imported.

The consumption of ferromanganese averages 190 000-250 000 tons per year. The deficiency of the materials is covered by import (up to 47 m.t.) from Ukraine, Norway, France and South Korea.

The production of silicon-manganese in Russia tends to grow from 50000 tons in 1997 to 230000 tons in 2016 (52\% of the consumption level). The consumption of siliconmanganese increased from 170000 tons in 1998 up to 230000 tons in 2016. The most of the demand of Russia (50-60\%) in silicon-manganese is satisfied by import from Ukraine and Kazakhstan. Total import value averages 245000 tons per year. Recently, a demand for metallic manganese, imported primarily from China, has appeared, up to 50000 t./year.

Nowadays, metallic manganese is not produced at industrial scale in Russia. World prices for ferromanganese and silicon-manganese were around 500 USD per $t$. in the period of time 1996 - 2003, nowadays -800 and 1,000 USD per t., respectively, and 1,700 USD per t. for manganese [4]. 

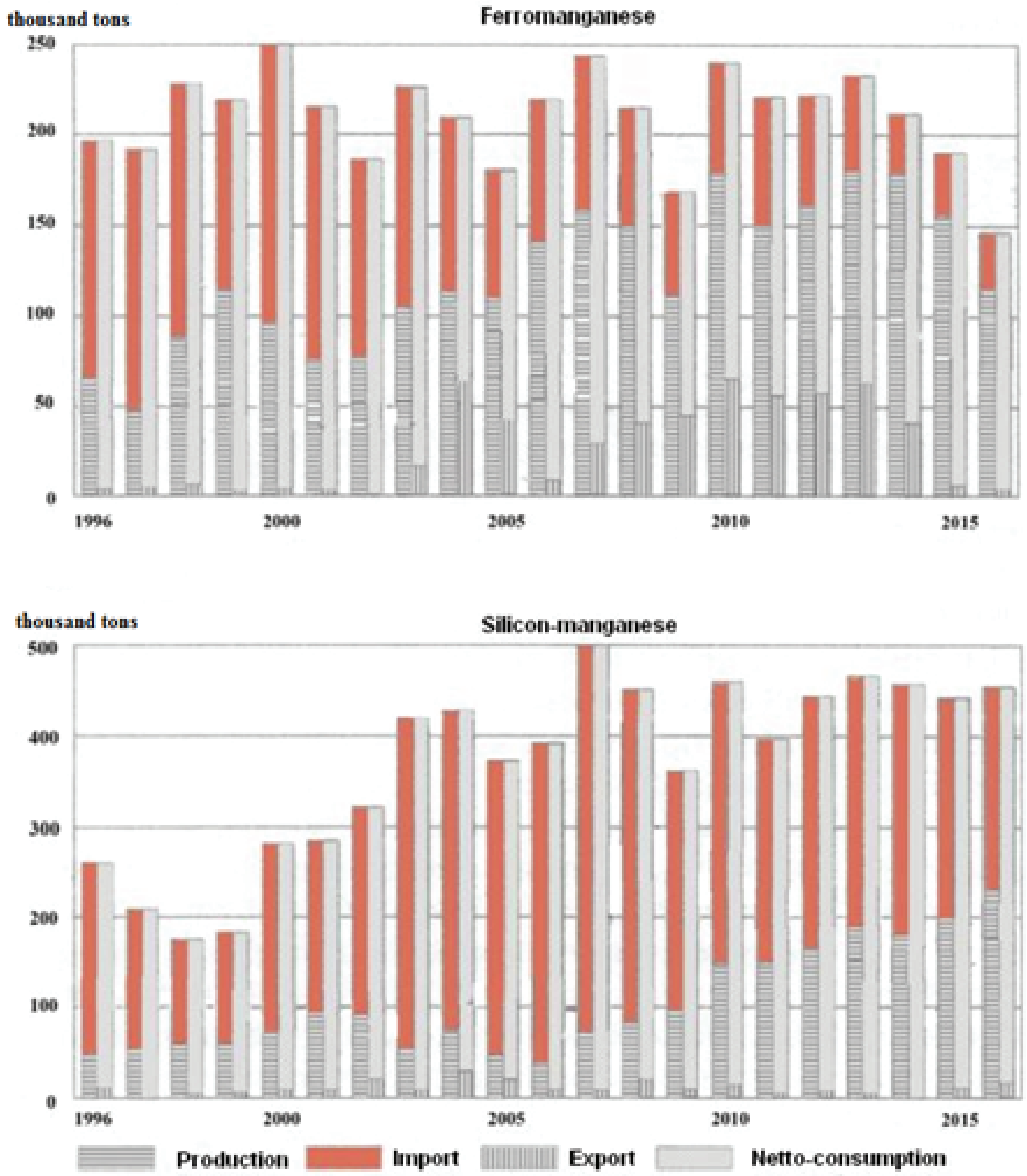

Figure 3: Flows of manganese ferroalloys in the Russian Federation [4].

Overall, the Russian metallurgy depends severely on the import of manganese products. Almost all manganese ores and concentrates, most of ferro- and siliconmanganese, and all manganese are purchased abroad [4]. Thus, it is necessary not only to form and develop stable and profitable import to the Russian Federation from near and far abroad but also to implement effective programs to eliminate the dependence on imports [8]. First of all, it should include involving the manganese ore reserves placed in Russia (according to the categories $A+B+C_{1}+C_{2}$, they are about 290 million 
tons), exploration of new reserves and larger-scale usage of all types of manganesecontaining wastes as metallurgical enterprises in Russia generate 170-250 tons of slag annually [9].

Since domestic manganese ores have a low contain of manganese and a high content of phosphorus, it is necessary to organize and intensify new scientific and applied investigations to enrich and dephosphorize these ores.

\subsection{Chromium ferroalloys}

In contrast with manganese alloys, Russia is fully supplied with chromium ferroalloys imported mainly from abroad. Domestic ores are quite limited in use (around 35\%). Ore extraction in Russia is at the level of 400000 t./year at $\mathrm{Cr}_{2} \mathrm{O}_{3}$ content of 37 - 39\%. The reserves $A+B+C_{1}+C_{2}$ are 51.2 million tons [10], estimated reserves - more than 540 million tons. At present, ore is being mined from the fields Saranovskoe (Ural, Perm region) and Tsentrlnoe (Polar Ural, Yamalo-Nenetsky AO, chromite-containing massif Raj-lz).

The Russian import of chromium concentrates fluctuates in different years from 640 000 to 1,110000 tons per year, and the bulk of the import (94\%) originates from Kazakhstan. Recent world prices for chromium raw materials are around 150 USD/t.

The production, import and export of ferrochromium in Russia from 1996 to 2016 are shown in the Figure 4. Depending on economic environment and world prices, the ferrochromium output in Russia fluctuated from 520-564 thousand tons per year in 2005-2008 to 280 thousand tons per year in 2016 [10].

There is a small amount of ferrochromium import (up to 84000 t./year), but the largest part of the produced ferrochromium, from 220000 up to 416000 t./year, is exported.

The metallic chromium production in Russia is at the level of $15000-17000$ t./year, while the bulk is exported, up to 17000 t./year. Recent world prices for ferrochromium average 1,300-1,900 USD/t.

The main producers of chromium ferroalloys in Russia are ChEMK, SerovFP and KluchevkyFP.

Thus, the involvement of domestic chromium raw materials and stable trading connections with Kazakhstan do not create tensions with chromium ore in the Russia Federation allowing to produce an excessive quantity of chromium ferroalloys and to export them $[4,5]$. 


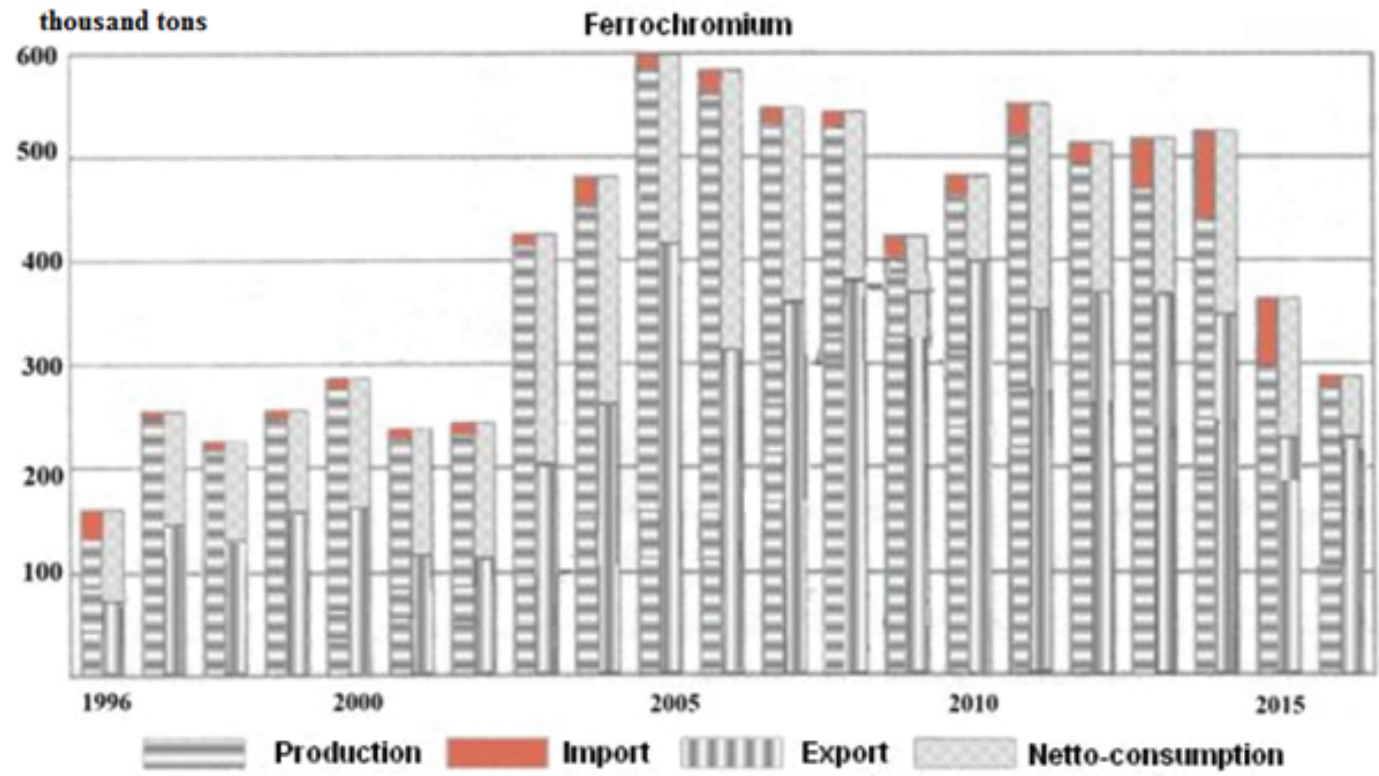

Figure 4: Ferrochromium flows to Russia [4].

\subsection{Silicon ferroalloys}

The output of ferrosilicon and crystal silicon in Russia exceeds its consumption in the country due to raw material reserves (quartzite, quartz), high productive capacity and consumer demands. The dynamics of ferrosilicon flow in Russia world prices are shown in the Figure 5.

The main producers of ferrosilicon are JSC "Kuznetskie Ferrosplavy", ChEMK, SerovFP, and crystal silicon - Bratsky Aluminum Plant. The output of silicon-based alloys in Russia averages almost a half of the total alloy output and reached 960-1,030 thousand tons in 2014-2016, at that the export was 450 thousand tons and apparent consumption was 530 thousand tons. World prices for ferrosilicon fluctuate from 2,000 to 3,000 USD/ton.

The production of silicon in Russia is at the level of $50000-60000 \mathrm{t}$./year, and up to 35000 t./year of it is exported. There is an import counter flow of crystal silicon up to 13000 t./year, too [4].

\subsection{Small-capacity ferroalloys}




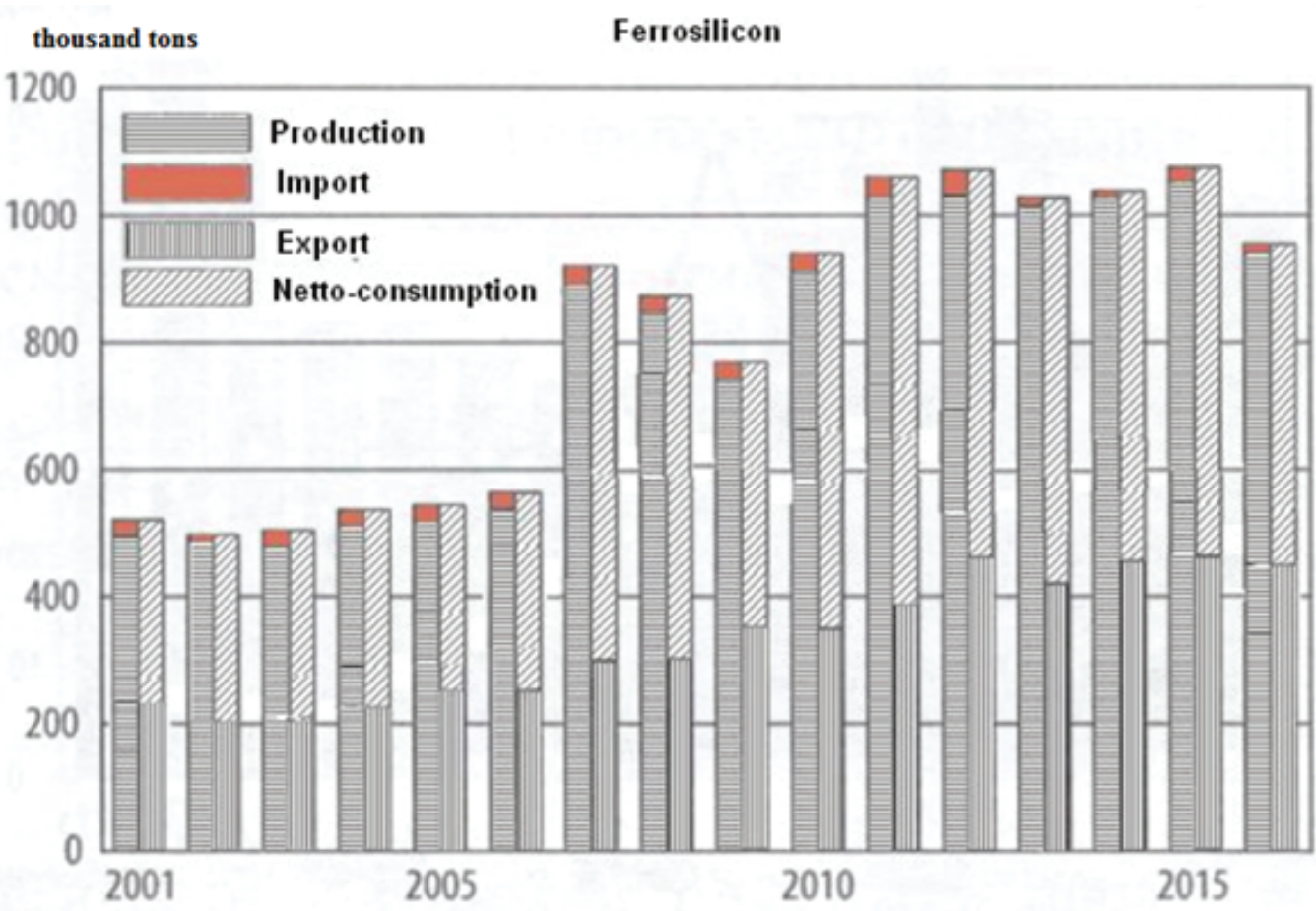

Figure 5: Ferrosilicon flow dynamics in Russia [4].

\subsubsection{Ferrovanadium}

The major type of raw materials for smelting ferrovanadium are vanadium concentrates obtained from the titanomagnetite of Kachkanar and Gusevogorsk fields (Ural) according to the following chain: ore $\rightarrow$ blast-furnace smelting $\rightarrow$ conversion $\rightarrow$ slag chemical treatment $\rightarrow$ vanadium concentrates.

In the Russian Federation, ferrovanadium is manufactured by OJSC "EVRAZ Vanadiy Tula" and OJSC "Chusovskoy metallurgical plant". The output of ferrovanadium in Russia in 2016 was around 12000 tons, while 2 000. of it was exported and 10000 t. consumed [4]. One more source for obtaining ferrovanadium is vanadium-bearng heavy crude oil and its processing is organized in Canada and Venezuela [11]. The price for ferrovanadium fell from 30,000 USD/t. in 2014 to 18,000 USD/t. in 2016.

\subsubsection{Ferromolybdenum}

The manufacture of ferromolybdenum in Russia discontinued in 1990s and resumed in 2011 starting with a smaller output of 250 t. and reaching 7000-9000 t. by 2008 . Nowadays it runs at relatively small specialized ferromolybdenum plants such as Sorsky (Khakasiya), Zhirekensky (Chita region) and others. The main part of ferromolybdenum, 
$78 \%$, is exported. World prices for the ferroalloy fell quite drastically - from 70,000 USD/ t. in 2007 down to 10,000 USD/t. in 2016 [4].

\subsubsection{Ferroniobium}

At significantly increased consumption of ferroniobium by Russian steel plants from 200$300 \mathrm{t}$./year in the end of 1990s up to 4000-6500 t./year in the present time, its production in Russia is only 200 t./year. This situation is caused by the absence of mines in operation in spite of having rich niobium fields such as Tomtorskoe in Yakutia and Beloziminskoe and Chuktukonskoe in the Irkutsk region [4]. In general, ferroniobium is imported from Brazil (75-90\%), and some part comes from Canada and France.

Since 2012 and until nowadays, the price for ferroniobium dropped from 25,000 to 20,000 USD/t.

\subsubsection{Ferrotungsten}

Tungsten concentrate is produced in Russia with a rate of 4000-5000 t./year, additional 1100-1700 tons are purchased (basically in China), and 3000-5000 tons of the concentrate is exported. The bulk of the tungsten concentrate is processed into tungsten anhydride, ammonium paratungstate and tungsten carbide at the enterprises "Gidrometallurg" (Nalchik) and Kirovgrad plant of hard alloys (Sverdlovsk region). According to [4], ferrotungsten is manufactured at Ryazan plant of ferroalloys and addition alloys as well as LLC "Moliren" (Moscow region). Prices for ferrotungsten fluctuate from 15,000 up to 35,000 USD/ton.

\subsubsection{Ferrotitanium}

The output of ferrotitanium in Russia before 2004 was $30000-40000$ t./year, but when the price for the alloy fell from 20,000 to $3,000 \mathrm{USD} / \mathrm{t}$., its production was reduced to 10 000-12 000.t./year. Almost all ferrotitanium is exported. Producers: PJSC "The Corporation VSMPO-AVISMA" (Sverdlovsk region), LLC "Kanta” (the city of Chelyabinsk) and others. 


\subsubsection{Ferronickel}

The output of ferronickel is basically influenced by the price on the world market. Before 2014, the price for nickel was 7,000-8,000 USD/ton and the export flow was 30000-40000 t./year. In 2015, when the price dropped to 1,700 USD/ton, the export flow decreased to 700-2200. t./year. T. The main producers of ferronickel are YuzhnoUralsky nickel factory and Buruktalsky nickel plant (Orenburg region), etc. [4].

The provided overview shows that all ferroalloys produced in Russia can be divided into three groups: import-dependent, export-oriented and the group of import-export.

The summarized maximum import flow of ferroalloys and raw materials to Russia averages 2,600 metric tons with a cost of 1 billion USD, and the export one - 1,000 metric tons with a cost of 1.7 billion USD [4].

A traditional challenge for ferroalloy enterprises in Russia is improving the competitiveness at the expense of reducing production costs and improving the production quality as well as solving the issue of import substitution for certain types of ferroalloys. To fulfill the challenge, it is necessary to focus on the following directions:

1. investigation and organization of rational utilization of poor domestic raw materials such as chromium and manganese ores;

2. variation of ferroalloy production assortment in the direction of increasing the output of effective alloys for microalloying and modification of steel that will allow to improve its quality and reduce the specific consumption of ferroalloys;

3. increasing the quality of ferroalloys by lowering the content of harmful impurities (phosphorus, sulfur, arsenic, titanium, aluminum, etc.), non-metal inclusions and gases;

4. organization of sectors for the rational pre-smelting preparation of raw materials (fraction classification of raw materials, coarsening of small particles) at ferroalloy enterprises;

5. re-equipment of enterprises with new designed furnaces and modernization of outdated furnaces;

6. energy saving at ferroalloy enterprises with use of more effective utilization of chemical and thermal energy of blast furnace gases and heat of electric furnaces, and recycling of production wastes;

7. ferroalloy process automation which allows improving technical and economic indices as well as maintenance procedures; 
8. development of ferroalloy casting methods aimed at output increasing and resource saving.

The majority of the mentioned problems were discussed earlier in $[5,12]$ but they were not solved in practice.

A few problematic directions deserve to be mentioned concerning the development of theory and practice of ferroalloy production which are under consideration in the metallurgical institutes of RAS.

Until 1990s ferroalloy plants in USSR were fully supplied by manganese raw materials from Ukraine and Georgia and by the chromium ones from Kazakhstan. In the recent time, all manganese two third of chromium ferroalloys in Russia are obtained with use of imported raw materials. Basically, it is caused by the limited development of domestic fields, low-qualified raw materials and the absence of effective manufacturing schemes. The main disadvantage of these ores is a low content of the target element (manganese, chromium) and high content of phosphorus (for manganese ores).

Ore enrichment is not always economically rational and may involve significant losses of the target elements and additional coarsening of small particles. A condition of mineral resources of manganese and chromium ores does not allow Russia to become selfsufficient and stop their import. However, by increasing the involvement of explored and new ore reserves with a relatively low quality, the state program of import substitution is going to be implemented. Perspective directions such as using low content manganese and chromium raw material can help with it. Besides a rational addition batching of poor domestic ores to the rich imported ones in obtaining standard types of ferroalloys, it is suggested:

1. to obtain new alloys with a lowered content of the target element and complex ferroalloys;

2. to obtain pig ferroalloys and to use them to smelt refined sorts of ferromanganese and ferrochromium.

For poor chromite ores it is rational to selectively reduce the ore components with division into a metallic semi-product with reduced chromium content suitable for stainless steel smelting and a product with a high of content $\mathrm{Cr}_{2} \mathrm{O}_{3}$ suitable for ferrochromium smelting [13].

A problem of phosphorus content decreasing in the ferroalloys obtained from manganese ores with a high content of phosphorus $(0.2-0.6 \% \mathrm{P})$ is under consideration for many years. So far, only obtaining a slag with low phosphorus content by electric 
furnace smelting is in use, and the problem needs to be addressed as ferroalloys with high phosphorus content are not in great demand. One of the perspective directions for dephosphorization of manganese raw materials is purging the melt with reducing gases with [14].

One more problem of ferroalloys manufacturing is that the standards for ferroalloys were created when the main technology for making steel was the open-hearth process and have not significantly changed so far. During the process of steel production, some new technological elements have appeared, such as ladle refining and continuous casting, which demanded a new quality level for ferroalloys tied basically with temperature and time features of their melting. Ore raw materials for smelting almost all types of ferroalloys have changes as well. All of this requires creating new types of ferroalloys with new performance features. Ferroalloys features should be improved based on the study of the effect of alloying elements on the properties of these ferroalloys; the properties are density, melting temperature, time of melting and oxidability.

Based on a physical-chemical investigation of ferroalloy characteristics and processes of their interaction with a ferricarbonic melt, a method for the determination of rational composition of ferroalloys has been applied $[15,16]$. The method was also used to create new ferroalloys with vanadium, niobium, chromium, boron and other elements. For instance, a creation of new iron-silicon-boron alloys allowed increasing assimilation of boron by steel by $10-25 \%$ with decreasing costs for its production. These alloys were made in industrial systems and applied to smelt steel.

Unfortunately, consumers are basically indifferent to new types of ferroalloys, although these ferroalloys have usually better characteristics.

Despite the Government of the Russian Federation issues standing instructions and finances environmental protection, the situation with generating and consuming own wastes of ferroalloy manufacturing and processing costs is unfavorable $[9,17]$.

The waste reduction problem in metallurgy is being addressed in three directions:

1. reducing the amount of waste caused by technological factors;

2. maximum reducing all wastes with a minimal release to the environment;

3. effective processing and complete utilization.

Waste generation at ferroalloy plants occurs in the form of slags, dusts, gas purification sludges and ferroalloy gases. Their waste formation rate depends on the type of charge materials and manufacturing technology. The main wastes are slags. 
In Russia, the slag generation rate is $\mathbf{5 7}$ metric tons per year remaining from the ferrosilicon alloy production, 531 m.t./year - from the chromium ones, 170 m.t./year - from the chromium ones, total slag rate - ca 760 m.t./year, and ca 140 m.t./year of dusts and sludges [9]. Wastes of various ferroalloy productions have their specific compositions and properties. For instance, ferrosilicon slags have a high content of $\mathrm{SiO}_{2}$, slags of chromium alloys $-\mathrm{MgO}$ and $\mathrm{Cr}_{2} \mathrm{O}_{3}$, slags of manganese alloys $-\mathrm{MnO}$ and $\mathrm{CaO}$. Chemical and granulometric composition of wastes defines their properties and the field of application. As an example, it is possible to utilize gas purification sludges (they contain 20 $43 \%$ of $\mathrm{Cr}_{2} \mathrm{O}_{3}$ ) generated at chromium ferroalloy manufacturing as an addition at making fired pellets. Also, there is an implemented manufacture where manganese slags are utilized to produce cast slag-stone workpieces with high performance characteristics.

To define ways to involve man-made materials (slags, dusts, sludges) in the process of ferroalloy manufacturing, a thorough metallurgical, techno-economic and social assessment should be undertaken to estimate physical-chemical properties of the materials and how effectively their usage could reduce the pollution load.

Thus, in the conditions of domestic and global competition for ferroalloy market and increase of import substitution, strengthening the competitiveness of Russian ferroalloy enterprises due to reducing production costs and improving quality of products remain an important challenge.

Taking into account the strategic importance of ferroalloy industry, necessity to create and involve into manufacturing domestic manganese and chromium ores, as well as other basic problems, achieving the objectives has to be realized by enterprises with government assistance.

\section{References}

[1] Zinovieva, N.G. (2018). Statistics. Bulletin “Ferrous Metallurgy”, no. 3, pp. 122-125.

[2] Zemlyanskaya, L. and Kasatkin, D. (2018). Review of the iron and steel market. URL: https:/www2.deloitte.com/ru/pages (9.06.2018).

[3] Mukatdinov, N.Kh., et al. A development strategy of the iron and steel metallurgy in Russia for the period of time 2014-2020 and further 2030, in Proceedings of the $13^{\text {th }}$ International Conference of Steelmakers. Polevskoy, Sverdlovsk region: JSC "Seversky Pipe Plant.

[4] Boyarko, G.Yu. and Khat'kov V.Yu. (2018). Flows of ferroalloys in Russia. Non-ferrous metals, no. 3, pp. 60-63.

[5] Leontiev, L.I., et al. (2015). Ferroalloy production in Russia. Steel, no. 10, pp. 21-25. 
[6] Khodina, M.A. Russian market of manganese production. (2017). Prospect and protection of mineral resources, no. 2, pp. 42-48.

[7] Metal Research. Ferroalloys market 2017-2018: manufacturing in Russia. URL: http: //www.metalresearch.ru/ferroalloys_market_2017-2018.html

[8] Zhuchkov, V.I., et al. (2007). The technology of manganese ferroalloys. High-carbon manganese ferroalloys. Yekaterinburg: UB RAS.

[9] Zhdanov, A.V., et al. (2014). Waste generation at ferroalloy production. Metallurgist, no. 12, pp. 36-41.

[10] Commodity complex of Russia. Chromium ores. URL: https:/www.mineral.ru/Facts/ russia/161/549/306cz.pdf. (22.07.2015).

[11] Sukhanov, A.A., et al. (2012). Evaluation of industrial development of metal-bearing potential of oils and possible ways of its implementation. Oil and gas geology. Theory and practice, vol. 7, no. 4, p.15.

[12] Leontiev, L.l., et al. (2015). Situation and perspectives of ferroalloy production in Russia. Metallurgist, no. 11, pp. 11-15.

[13] Zhuchkov, V.l., et al. (2008). Main directions to process poor domestic chromium raw materials. Electric Metallurgy, no. 5, pp. 18-21.

[14] Dashevsky, V.Ya., et al. (2017). Dephosphorization of manganese ores and concentrates, in Proceedings of Physical-Chemical Principles of Metallurgical Processes. Moscow: IMET RAS.

[15] Zhuchkov, V.I., et al. (2005). Study of physical-chemical characteristics of ferroalloys and tuning their rational composition, in Proceedings of Physical Chemistry and Technology in Metallurgy. Yekaterinburg: UB RAS.

[16] Zhuchkov, V.I., et al. (2013). Composition and performance of chromium-bearing ferroalloys. Steel in Translation, vol. 43, no. 5, pp. 306-308.

[17] Zhuchkov, V.I. and Zayakin, O.V. (2010). Environmental activities in ferroalloy manufacturing. Melts, No. 5, pp. 3-6. 